\title{
Terrain Selection by Reindeer in Late Winter in Central Norway
}

\author{
CHRISTIAN NELLEMANN ${ }^{1}$
}

(Received 19 December 1995; accepted in revised form 13 June 1996)

\begin{abstract}
Characteristics of topography, snow, lichen cover, and lichen distribution were compared with habitat use by Snøhetta reindeer (Rangifer tarandus tarandus L.) in central Norway to investigate the role of terrain structure for habitat use within different lichen heath communities. In late winter, density of groups of feeding craters was correlated to indices of terrain ruggedness (TRI) measured at a mesoscale (10-20 m relief), but not to terrain ruggedness measured at a macroscale (30-110 $\mathrm{m}$ relief). The use of lichen heaths in rugged terrain (TRI $>2.0$ ) was higher than that expected from availability. In rugged terrain, $60-80 \%$ of the lichen heaths had less than $40 \mathrm{~cm}$ of snow, compared to only $10-30 \%$ of the lichen heaths in less rugged areas (TRI < 2.0). Rugged terrain types accounted for only $23 \%$ of the lichen heath in the study area, and less than $9 \%$ of the total area. Available habitat was thus considerably less than that suggested by overall availability of alpine lichen heath. In late winter, ramhardness of snow exceeded $40 \mathrm{~kg}$, and reindeer cratered mainly where snow was less than $20 \mathrm{~cm}$ deep. Reindeer selected narrow (15-25 m broad) and sparsely vegetated ridges with high microtopographic diversity beyond that suggested from availability. Other ridge types with lichen heath were used less than expected from availability. Terrain ruggedness indices may have the potential for estimating the proportion of lichen heath communities that are available in late winter when snow conditions limit availability of forage.
\end{abstract}

Key words: forage, reindeer, snow, terrain, winter

RÉSUMÉ. On a comparé des caractéristiques relatives à la topographie, à la neige, à la couverture de lichen ainsi qu'à sa répartition avec l'utilisation de l'habitat par le renne Snøhetta (Rangifer tarandus tarandus L.) dans le centre de la Norvège pour savoir quel rôle joue la structure du terrain dans l'utilisation de l'habitat au sein de diverses communautés de bruyère lichénique. À la fin de l'hiver, la densité des regroupements de fosses de broutage a été corrélée avec les indices d'accidents de terrain (IAT) mesurés à échelle moyenne (de 10 à 20 m de dénivellation), mais pas avec les accidents de terrain mesurés à macroéchelle (de 30 à $110 \mathrm{~m}$ de dénivellation). L'utilisation de la bruyère lichénique en terrain accidenté (IAT $>2,0$ ) était plus élevée que la disponibilité ne le laissait prévoir. En terrain accidenté, de 60 à 80 p. cent de la bruyère lichénique avait moins de $40 \mathrm{~cm}$ de neige, par rapport à 10 à 30 p. cent seulement de la bruyère lichénique dans des zones moins accidentées (IAT < 2,0). Les types de terrain accidenté comptaient pour seulement $23 \mathrm{p}$. cent de la bruyère lichénique dans la zone d'étude et pour moins de 9 p. cent de la superficie totale. L'habitat disponible était donc infiniment moindre que ne le laissait croire la disponibilité d'ensemble de la bruyère lichénique alpine. À la fin de l'hiver, la dureté de la neige mesurée au pénétromètre dynamique était supérieure à $40 \mathrm{~kg}$, et les rennes creusaient surtout là où la neige avait moins de $20 \mathrm{~cm}$ de profondeur. Les rennes choisissaient des crêtes étroites (de 15 à $25 \mathrm{~m}$ de largeur) à végétation dispersée, dont la forte diversité microtopographique était bien supérieure à ce que suggérait la disponibilité. D' autres types de crêtes au couvert de bruyère lichénique étaient moins utilisées que ne le suggérait la disponibilité. Les indices d'accidents de terrain pourraient éventuellement servir à évaluer la proportion des communautés de bruyère lichénique qui sont disponibles à la fin de l'hiver lorsque l'enneigement limite l'accès au fourrage.

Mots clés: fourrage, renne, neige, terrain, hiver

Traduit pour la revue Arctic par Nésida Loyer.

\section{INTRODUCTION}

In alpine and arctic regions, reindeer and caribou (Rangifer tarandus ssp.) populations often feed on lichen communities dominated by Cladina and Cetraria spp. during late fall and early winter (Scotter, 1966; Gaare and Skogland, 1975; Thompson and McCourt, 1980; Helle, 1984; Thomas and Hervieux, 1986; Nieminen and Heiskari, 1989). This period is usually characterized by soft and shallow snow, which allows for cratering and frequent movement between feeding locations (Pruitt, 1981; Skogland, 1984). Reindeer and caribou have several physiological adaptations to a low-protein and low-mineral winter diet (McEwan and Whitehead, 1970; Hyvärinen et al., 1977; Staaland et al., 1983, 1986). Unless starvation occurs, they may perform well during long periods of winter when little forage is available (Hyvärinen et al., 1977; Gates et al., 1986; Tyler and Blix, 1990; Aagnes and Mathiesen, 1994). In late winter, when snow hardness and

${ }^{1}$ Department of Biology and Nature Conservation, P.O. Box 5014, Agricultural University of Norway, N-1432 Ås, Norway; present address: Norwegian Institute of Land Inventory, Drøbakveien 11, N-1430 Ås, Norway

(C) The Arctic Institute of North America 


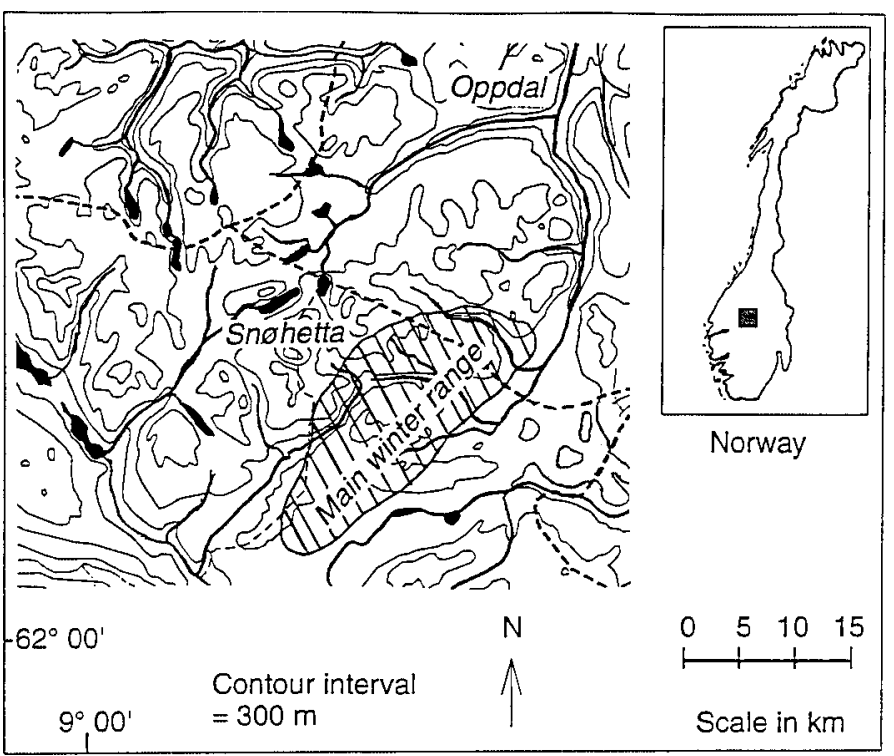

FIG. 1. The location of the study area in the Dovre Mountains in Central Norway. Winter grounds are marked.

snow depth increase (Pruitt, 1979; Duquette, 1988; Collins and Smith, 1991), reindeer and caribou reduce their movements, move to more exposed sites with lower forage biomass, and increase cratering activity in order to sustain body reserves (Pruitt, 1966; Bergerud, 1974; LaPerriere and Lent, 1977; Thing, 1977; Skogland, 1978). Competition for food in late winter may limit population size, even if overgrazing has not already occurred (Miller et al., 1975; Reimers, 1977, 1982, 1983a; Helle and Säntti, 1982; Skogland, 1983, 1985, 1986; Roby and Thing, 1985). While the quality of spring and summer ranges is important for the size and weight of Rangifer (Reimers, 1972; Reimers et al., 1983), estimates of forage availability in late winter may be particularly important for evaluating carrying capacities (Skogland, 1983, 1985; Gates et al., 1986).

Lichen heath communities and exposed ridges can be found across the landscape in most parts of arctic and alpine environments. In spite of this, reindeer and caribou are often quite specific in their selection of winter grounds (Henshaw, 1968; Bergerud, 1974; Baskin, 1990). In recent years, remote sensing has been used to map summer forage, snow cover, distribution of lichen heath communities, and grazing pressure (Tømmervik et al., 1990; Hall et al., 1991; Pearce, 1991). Vegetation distribution has also been used to estimate carrying capacities for reindeer in different areas, particularly in winter (Skogland, 1986; Tømmervik et al., 1990). However, distribution of vegetation alone may not provide reliable information on forage availability in late winter, when access is limited by deep and packed snow (Bergerud, 1974; Brooks and Collins, 1984; Nellemann and Fry, 1995). Beyond reindeer selection of lichen heath communities on ridges with reduced snow cover (Pruitt, 1966; Bergerud, 1974; Thing, 1984; Adamczewski et al., 1988; Tucker et al., 1991), our knowledge of specific micro- and macrotopographical components that contribute to habitat choice is very limited. It is important to identify the combined terrain and vegetative characteristics that contribute to selection of winter feeding sites, since this may improve understanding of reindeer winter habitat requirements and thus carrying capacities.

The occurrence of windblown ridges indirectly determines the availability of sites with shallow snow cover in winter (Nellemann and Fry, 1995). The analysis of topography should therefore provide a simple means of determining forage availability. However, little is known about the scales at which terrain ruggedness should be measured to depict forage availability. While reindeer are known to select for lichen heath communities, little is known about how reindeer choose among different ridge types depending upon lichen cover and microtopographic relief within the ridges. The use and preference among different terrain and vegetation types are clearly relevant for management, since this information may help us understand the range requirements of reindeer. In this study, the objective was to provide a better understanding of the relationships between feeding distribution of reindeer, topographic ruggedness, forage availability, and snow conditions. I also sought to describe the different scales at which selection may occur, by analyzing use of both rugged terrain and flatter terrain, as well as use within rugged terrain only, by comparing use of different "ridge" types used by Snøhetta reindeer.

\section{STUDY AREA}

The study was conducted during late winter 1993 in the Dovre Mountains in central Norway, where approximately 1000-1500 wild, free-ranging reindeer from the Snøhetta reindeer herd have their winter grounds (Fig. 1). The herd is regulated mainly through hunting, and has been stable in recent years. The study area included a $50 \mathrm{~km}^{2}$ area used intensely during winter 1992-93. The area is a typical alpine environment with considerable variation in terrain structure. Elevation ranges from 1000 to $2200 \mathrm{~m}$ above sea level (a.s.l.), with mountain plateaus, rolling hills, glacial deposits, and many ridges and bluffs of varying form and length. The area is dominated by alpine vegetation, ranging from snowbed vegetation to lichen heath communities and barren rock. Terrain more than $1700 \mathrm{~m}$ a.s.l. is mostly unvegetated. The area is generally snow-covered from late October to late May. Annual precipitation is approximately $430 \mathrm{~mm}$.

\section{METHODS}

Sampling sites were first visited in March 1993, and then revisited during the snow-free season in July the same year. All sampling was done between 1200 and $1700 \mathrm{~m}$ a.s.l. Assessment of use and habitat characteristics was done at two levels: (1) selection of terrain types ( $1 \mathrm{~km}^{2}$ quadrats); and (2) selection of individual ridges $(20 \times 50 \mathrm{~m}$ sites $)$ within rugged terrain only. 


\section{Selection of Terrain Types}

Within the study area, 15 quadrats, each $1 \mathrm{~km}^{2}$, were randomly chosen from a grid of $1 \times 1 \mathrm{~km}$ quadrats that covered the entire winter range. Terrain ruggedness indices (Nellemann and Thomsen, 1994; Nellemann and Fry, 1995) were calculated for each $1 \mathrm{~km}^{2}$ quadrat on 1:50 000 topographic maps (contour interval $20 \mathrm{~m}$ ). The index of terrain ruggedness was based on the total number of contour lines (TNC) intercepted along the transect, and total number of fluctuations (TNF) encountered along the same transect. TNF in a terrain surface was defined by the number of separate aspects resulting from occurrence of anti- and synclinals along the transect. An area with considerable changes in relief (many anti-/synclinals) and many contour intercepts has a high value of ruggedness, while smooth terrain has a low value. To reduce the effects of extreme values of either component on index values, the following equation was used to calculate the terrain ruggedness index (TRI):

$$
\mathrm{TRI}=(\mathrm{TNC} \times \mathrm{TNF})(\mathrm{TNC}+\mathrm{TNF})^{-1}
$$

The index was calculated for each quadrat, with one $1 \mathrm{~km}$ long transect placed across the center of each $1 \mathrm{~km}^{2}$ quadrat so that it intersected the greatest possible variation in relief (Nellemann and Thomsen, 1994; Nellemann and Fry, 1995). Terrain ruggedness indices were calculated for maps with contour intervals of $10 \mathrm{~m}, 20 \mathrm{~m}$ (mesoscale), $30 \mathrm{~m}$, and 110 m (macroscale) (Nellemann and Fry, 1995). Thus, it was possible to identify that scale of terrain ruggedness which best reflected reindeer use and habitat characteristics.

In late March, after two weeks without precipitation, all feeding locations (groups of feeding craters with more than five individual craters) were counted within a $1 \mathrm{~km}$ belt plot (300 m wide) extending $150 \mathrm{~m}$ on either side of the terrain ruggedness transects. Snow depths were recorded within lichen heath communities at 100 random points along each transect and ram-hardness was measured on 25 random points (Skogland, 1978). Points of measurement were randomized using a $20 \times 20 \mathrm{~m}$ grid on the 1:25000 map, divided in the field into $5 \mathrm{~m}$ segments. Terrain ruggedness and density of feeding craters were compared using polynomial regression analysis.

All feeding locations were marked on a 1:50 000 fieldbased vegetation map of the area from the Norwegian Institute for Land Inventory (Larsson and Rekdal, 1991). For practical reasons, the smallest vegetation unit delineated on the map was 1 ha. For simplicity, all lichen heath communities within the 15 quadrats on this map were classified into four "ridge" types on the basis of lichen cover and microtopography: (1) more than 20\% lichens with exposed rocks; (2) more than $20 \%$ lichens without exposed rocks; 3 ) less than $20 \%$ lichens with exposed rocks; or (4) less than $20 \%$ lichen cover without exposed rocks. Coverage of these ridge types within each of the 15 quadrats was determined using a planimeter. The frequency of sites with less than
$40 \mathrm{~cm}$ snow (Henshaw, 1968; Duquette, 1988; Nellemann and Fry, 1995) within these lichen heaths was related to terrain ruggedness using polynomial regression. This was done to estimate the proportion of lichen heaths with shallow snow cover in different terrain types. The relationship between distribution of the four ridge types and density of groups of feeding craters was assessed using polynomial regression. Use versus availability of ridge types was assessed using the chi-square goodness-of-fit test. When a significant difference was detected, the Bonferroni $z$-statistic was used to determine which habitat types were used more or less frequently than expected (Neu et al., 1974). Evaluation of reindeer preferences among the four ridge types was based on available lichen heath, not proportions of the entire study area, since reindeer use was confined to those four types. For all habitat types, the expected occurrence $n p$ was greater than five (Thomas and Taylor, 1990).

\section{Selection among Individual Ridges}

Within the four ridge types in rugged terrain used by reindeer, 31 sites $(20 \times 50 \mathrm{~m})$ were randomly selected using the $20 \times 20 \mathrm{~m}$ grid on the 1:25000 topographic map. Terrain, snow, and vegetative characteristics were compared for the 31 sites. Within each site, five plots $(5 \times 5 \mathrm{~m})$ were randomly selected and coordinates marked. On these plots, Ram-hardness and five snow depths were recorded (Skogland, 1978). Ram-hardness was measured using a Ram-sonde. To compute an integrated Ram-hardness index (IRH) including both snow depth $(\Delta \mathrm{d}, \mathrm{cm})$ and hardness (H(r), kg) (Pruitt, 1979; Tucker et al., 1991), the following equation was used:

$$
\mathrm{IRH}=(\mathrm{H}(\mathrm{r}) * \Delta \mathrm{d})
$$

In July, microtopographic diversity was estimated by measuring the horizontal distance of a $3 \mathrm{~m}$ long chain laid in a straight line following the ground surface across the center of each $5 \times 5 \mathrm{~m}$ plot (Nellemann and Thomsen, 1994). The difference between chain length and horizontal distance measured thus becomes an index of microtopographic diversity. Additionally, all surface rocks and boulders within the plots were counted and placed in two classes: 1) those with diameters of $20-50 \mathrm{~cm}$ and 2) those with diameters greater than $50 \mathrm{~cm}$. The relative use of each site by reindeer was also determined by counting the number of individual pellet groups on all plots. From the center of each plot, the width and length $(\mathrm{m})$ of the lichen community were measured, and a mean for both length and width for the site was calculated.

Within each $5 \times 5 \mathrm{~m}$ plot, the percent cover of Betula nana, Cladina mitis, C. alpestris, C. rangiferina, Cetraria cucullata, C. nivalis, $C$. delisei, Stereocaulon paschale, and Alectoria spp. were estimated by counting the number of $10 \times 10 \mathrm{~cm}$ cells having more than $50 \%$ cover out of 100 cells possible on $1 \mathrm{~m}^{2}$ vegetation frames (Wratten and Fry, 1980; Nellemann and Thomsen, 1994). 
Statistical analysis was performed in SIGMASTAT (Jandel, 1992). Data were subjected to a KolmogorovSmirnov test for normality. For multiple comparisons, a Kruskal-Wallis ANOVA with Dunn's test on ranked data was used. Two-sample situations were compared using MannWhitney tests. Assessments of the relationship between number of feeding sites and terrain ruggedness at different scales was done using polynomial regression; $p$-values less than 0.05 were considered statistically significant.

\section{RESULTS}

\section{Selection of Terrain Types}

The number of feeding locations increased with increasing ruggedness of terrain measured at $10 \mathrm{~m}$ contours $\left(\mathrm{r}^{2}=0.70\right.$, $p<0.05)$ and $20 \mathrm{~m}$ contours $\left(\mathrm{r}^{2}=0.88, p<0.01\right)$ (Fig. 2 ), but not with terrain ruggedness measured at the macroscale at $30 \mathrm{~m}$ contours $\left(\mathrm{r}^{2}=0.04, p=0.54\right)$ or $110 \mathrm{~m}$ contours $\left(\mathrm{r}^{2}=\right.$ $0.05, p=0.49$ ). Terrain ruggedness measured at relatively fine scales was therefore best for analyzing habitat use. In the following results, only mesoscale ruggedness (20 m relief) is considered.

All feeding locations were in lichen heath communities. Rugged terrain (TRI $>2.0$ ) was used beyond that suggested from availability $(p<0.01)$. There were no significant differences in the cover of lichen heath communities between rugged (TRI $>2.0)$ and non-rugged terrain $($ TRI $<2.0)(p=$ $0.33, \mathrm{n}=7$ and $\mathrm{n}=8$, respectively). Rugged terrain (TRI $>2.0$ ) accounted for only $22 \%$ of the total area vegetated with alpine lichen communities (above $1200 \mathrm{~m}$ altitude), and less than $9 \%$ of the alpine study area.

The selection of rugged terrain types was directly related to more favourable snow conditions in such terrain. The proportion of lichen heaths having shallow snow cover (less than $40 \mathrm{~cm}$ ) was highest in rugged terrain (Fig. 3). In rugged terrain, $50-80 \%$ (95\% confidence interval) of the sites in lichen communities had less than $40 \mathrm{~cm}$ of snow, while only $10-40 \%$ of the lichen heaths in less rugged areas had snow depths of less than $40 \mathrm{~cm}$ (Fig. 3). Integrated Ram-hardness was significantly lower in rugged terrain compared to less rugged areas $(483 \pm 11$ and $2076 \pm 130 \mathrm{~kg} \cdot \mathrm{cm}$, respectively, $\mathrm{n}=7$ and $\mathrm{n}=8, p<0.001$ ), indicating much easier access to forage when both hardness and snow depths were considered. Ram-hardness alone was not significantly different in rugged terrain compared to less rugged areas $(\mathrm{TRI}<2.0)(38 \pm 5 \mathrm{~kg}$ and $40 \pm 2 \mathrm{~kg}$, respectively; $p=0.96$ ).

\section{Selection among Individual Ridges}

Reindeer used ridges with more than $20 \%$ cover and exposed rocks more than would be suggested from availability (Table 1). This ridge type had significantly lower snow depth and integrated Ram-hardness (IRH) compared to other ridges with more than $20 \%$ cover, but not compared to ridges with modest lichen cover (less than 20\%) (Table 2).

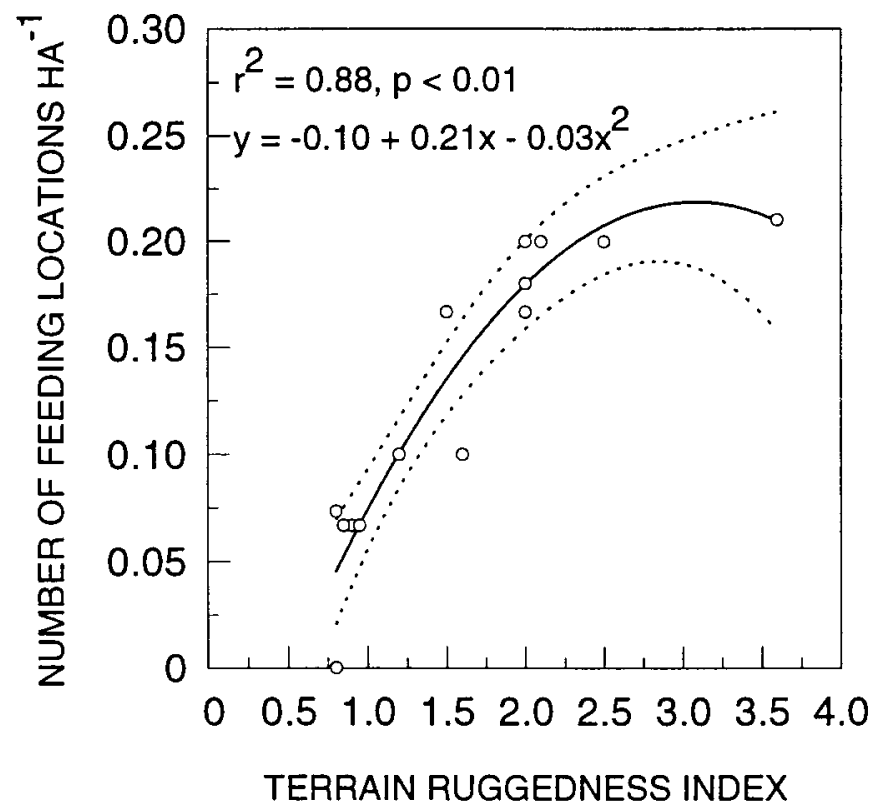

FIG. 2. Number of feeding locations (more than five feeding craters) per ha in relation to ruggedness of terrain (20 m contour intervals). A 95\% confidence interval is shown. Field sampling done in Dovre Mountains, Norway in 1993.

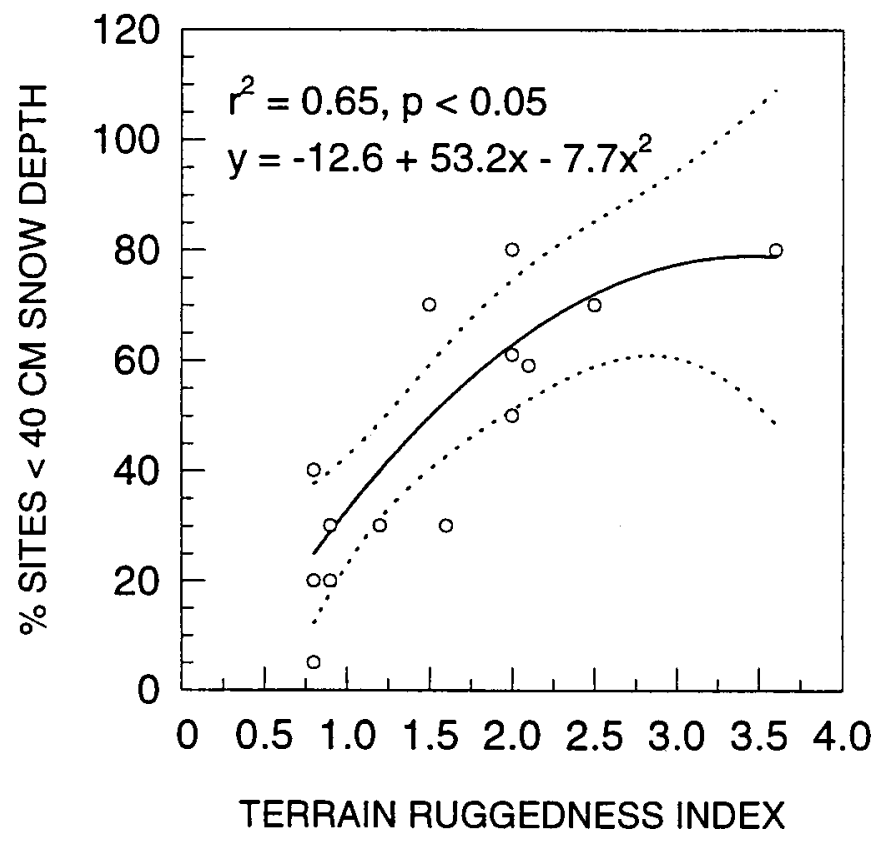

FIG. 3. The percentage of sites in lichen communities with more than $40 \mathrm{~cm}$ snow depth in relation to ruggedness of terrain ( $20 \mathrm{~m}$ contour intervals). A $95 \%$ confidence interval is shown. Field sampling done in Dovre Mountains, Norway in 1993.

Ram-hardness of snow was not significantly different among any of the ridge types $(p=0.616)$ (Table 2$)$.

Reindeer selected narrow $(15-25 \mathrm{~m}$ wide) windblown ridges with high microtopographic diversity caused by many exposed smaller rocks (Table 3 ). While narrow ridges generally had the least snow, lichen cover was also lower (Fig. 4a). However, among these narrow, sparsely vegetated ridges, reindeer selected for those with high microtopographic 
TABLE 1. Occurrence of feeding locations on ridges used by reindeer in late winter in two different lichen cover categories (\% cover), with (w) and without (wo) exposed rocks, in Dovre mountains, Norway in 1993.

\begin{tabular}{|c|c|c|c|c|}
\hline \multirow[b]{2}{*}{ Lichen cover } & \multicolumn{4}{|c|}{ Ridge type } \\
\hline & $<20 \%(\mathrm{w})$ & $<20 \%$ (wo) & $>20 \%(w)$ & $>20 \%$ (wo) \\
\hline Total area $\left(\mathrm{km}^{2}\right)$ & 2.34 & 2.90 & 2.00 & 1.71 \\
\hline Percent of area & 0.26 & 0.32 & 0.22 & 0.20 \\
\hline Observed number of feeding locations & 2 & 1 & 23 & 1 \\
\hline Expected number of feeding locations & 7 & 9 & 6 & 5 \\
\hline Proportion observed ${ }^{1}$ & 0.07 & 0.04 & 0.85 & 0.04 \\
\hline $95 \%$ confidence interval on proportion of occurrence & $(0 ; 0.21)$ & $(0 ; 0.13)$ & $(0.68 ; 1)$ & $(0 ; 0.14)$ \\
\hline Used more $(+)$ or less $(-)$ than expected ${ }^{1}$ & $(-)(p<0.05)$ & $(-)(p<0.05)$ & $(+)(p<0.05)$ & $(-)(p<0.05)$ \\
\hline
\end{tabular}

${ }^{1}$ All calculations according to Neu et al. (1974).

TABLE 2. Snow characteristics (mean $\pm \mathrm{SE}$ ) on ridges used by reindeer in late winter in two different lichen categories (\% cover), with (w) and without (wo) exposed rocks, in Dovre mountains, Norway in 1993.

\begin{tabular}{|c|c|c|c|c|}
\hline \multirow[b]{2}{*}{ Lichen cover } & \multicolumn{4}{|c|}{ Ridge type } \\
\hline & $<20 \%(w)$ & $<20 \%$ (wo) & $>20 \%(w)$ & $>20 \%$ (wo) \\
\hline Snow depth $(\mathrm{cm})$ & $13 \pm 0 \quad a^{1}$ & $8 \pm 1 \mathrm{a}$ & $12 \pm 2 a$ & $63 \pm$ \\
\hline Ram-hardness (kg) & $36 \pm 2.3 \mathrm{a}$ & $34 \pm 2 a$ & $38 \pm 3 a$ & $40 \pm 2 \mathrm{a}$ \\
\hline Integrated Ram-hardness & $447 \pm 16 \quad$ a & $375 \pm 40 a$ & $551 \pm 51 \mathrm{a}$ & $2297 \pm 151 b$ \\
\hline Number of ridge sites & 7 & 7 & 7 & 10 \\
\hline
\end{tabular}

${ }^{1}$ Different letters indicate significant difference $(p<0.05)$ (within row) using Kruskal-Wallis ANOVA with Dunn's test.

TABLE 3. Topographic characteristics on ridges used by reindeer in late winter in two different lichen cover categories (\% cover), with (w) and without (wo) exposed rocks, in Dovre mountains, Norway in 1993.

\begin{tabular}{lccccc}
\hline \hline & \multicolumn{5}{c}{ Ridge type } \\
\cline { 2 - 6 } Lichen cover & $<20 \%(\mathrm{w})$ & $<20 \%(\mathrm{wo})$ & $>20 \%(\mathrm{w})$ & $>20 \%(\mathrm{wo})$ \\
\hline Pellet density (groups ha $\left.{ }^{-1}\right)$ & $0 \pm 0 \mathrm{a}^{1}$ & $0 \pm 0 \mathrm{a}$ & $560 \pm 85 \mathrm{~b}$ & $55 \pm 50 \mathrm{a}$ \\
Size of ridge: & & & & & \\
$\quad$ Length (m) & $45 \pm 9 \mathrm{a}$ & $58 \pm 13 \mathrm{a}$ & $59 \pm 4 \mathrm{a}$ & $287 \pm 33 \mathrm{~b}$ \\
$\quad$ Width (m) & $14 \pm 2 \mathrm{a}$ & $13 \pm$ & $1 \mathrm{a}$ & $22 \pm 3 \mathrm{a}$ & $116 \pm 10 \mathrm{~b}$ \\
Microdiversity (index) & $25 \pm 2 \mathrm{a}$ & $6 \pm 3 \mathrm{~b}$ & $20 \pm 1 \mathrm{a}$ & $12 \pm 1 \mathrm{~b}$ \\
No. of rocks or boulders per $100 \mathrm{~m}^{2}:$ & & & & \\
$\quad 25-50$ cm diameter & $124 \pm 11 \mathrm{a}$ & $16 \pm 3 \mathrm{~b}$ & $54 \pm 5 \mathrm{bc}$ & $11 \pm 3 \mathrm{~b}$ \\
$\quad 350$ cm diameter & $36 \pm 07 \mathrm{a}$ & $2 \pm 1 \mathrm{~b}$ & $5 \pm 2 \mathrm{~b}$ & $2 \pm 1 \mathrm{~b}$ \\
Number of ridge sites & 7 & 7 & 7 & 10 \\
\hline \hline
\end{tabular}

${ }^{1}$ Different letters indicate significant difference $(p<0.05)$ using Kruskal-Wallis ANOVA with Dunn's test.

diversity, where lichen cover was more protected, and biomass relatively higher (Fig. 4b).

Used ridges had relatively higher occurrence of Cetraria nivalis, although cover was relatively low (Table 4). However, cover of lichens on Cetraria nivalis dominated sites was not significantly related to pellet group density $\left(\mathrm{r}^{2}=0.38, p<0.29\right)$, since only narrow communities with C. nivalis in rugged terrain were used. Reindeer apparently therefore firstly selected narrow ridges, and within these ridges those with Cetraria nivalis. Cover estimates generally reflected the biomass well $\left(\mathrm{r}^{2}=0.97, p<0.01\right)$ (Fig. 5).

\section{DISCUSSION}

Reindeer selected lichen heath communities located in rugged terrain, measured at the mesoscale, where forage availability was highest. This corresponds with the findings of Bergerud (1974) and Nellemann and Fry (1995). Rugged terrain, however, constituted only about one-fifth of the total area vegetated with lichen heath. Dahl (1956) reported snow depth varying from 0 to $140 \mathrm{~cm}$ within Cetraria and Cladina lichen heath at high elevations, confirming that great variation in forage availability exists within these vegetation types. Density of feeding craters was not correlated to distribution of lichen heath, but was correlated first to rugged terrain, and then to availability of lichen heaths. Within rugged terrain, reindeer locally selected narrow ridges with high microtopographic diversity. The relatively small number of groups of feeding craters $(n=27)$ in this type of habitat likely resulted in an underestimation of reindeer preferences for these habitats (Thomas and Taylor, 1990), since the craters represented several hundred reindeer. The groups of feeding craters were considerably larger on preferred ridges, which was reflected in the high density of pellet groups on preferred ridges (Table 3 ). The preference for rugged terrain and selection of ridge types based on microcharacteristics support the hypothesis that in late winter forage is much less available than distribution of general lichen heath communities would suggest.

Reindeer preferences could only be detected when terrain ruggedness was measured at fine scales. Hence, suitable rugged terrain may occur within mountain plains, on plateaus, or in the more mountainous and steep areas, which explains why reindeer can be found in all of these landscape types (Nellemann and Fry, 1995). Selection of rugged terrain, measured at a mesoscale, within these general landscape types may explain why reindeer are rather specific in selection of their winter grounds, despite the availability of other landscapes, apparently similar at coarse scales. Several winter grounds have been shown to have distinctly rugged terrain, measured at a mesoscale, when compared to low-use areas (Nellemann and Fry, 1995). These patterns emerged despite substantial differences in the general landscape types among high-use portions, and in spite of relatively similar distribution of lichen heaths in high and low-use portions of the winter grounds (Nellemann and Fry, 1995). 

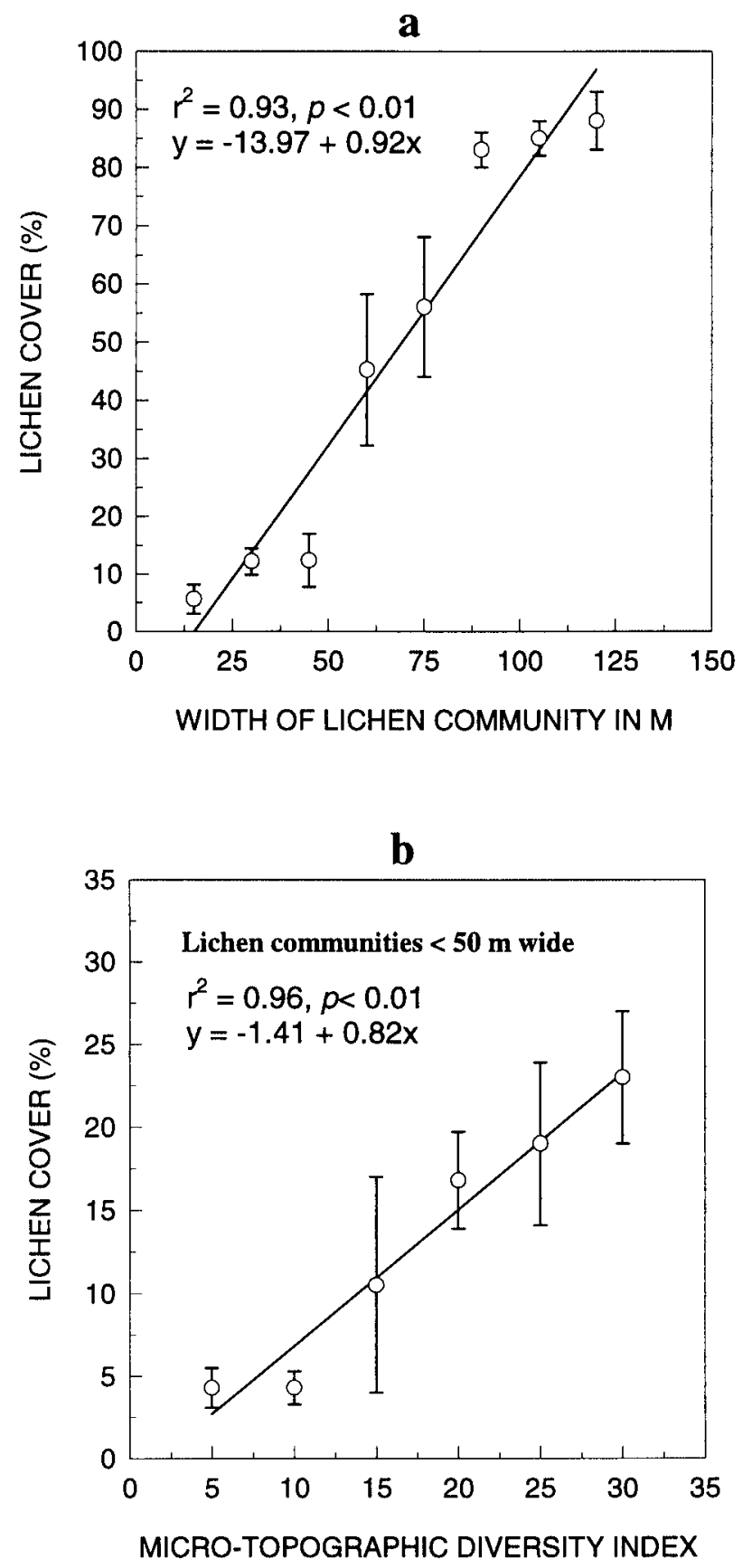

FIG. 4. Lichen cover in the Dovre Mountains, 1993: a) a function of the width of the lichen community (approximate width of ridge) for all ridges; and b) a function of microtopographic diversity within $0-50 \mathrm{~m}$ wide lichen heath communities.

Within the winter grounds, reindeer may utilize large lichen communities with high biomass during fall and early winter, when snow is shallow and soft. When snow hardness increases in late winter, reindeer select narrow ridges, where snow is more shallow. However, selection of feeding sites among narrow ridges is influenced by
TABLE 4. Cover of Cladina sp., Cetraria sp., Alectoria sp., Stereocaulon paschale, and Betula nana on ridges used by reindeer in late winter in two different lichen cover categories (\% cover), with (w) and without (wo) exposed rocks, in Dovre mountains, Norway in 1993.

\begin{tabular}{lccrr}
\hline \hline & \multicolumn{4}{c}{ Ridge type } \\
\cline { 2 - 5 } Lichen cover & $<20 \%(\mathrm{w})$ & $<20 \%(\mathrm{wo})$ & $>20 \%(\mathrm{w})$ & $>20 \%(\mathrm{wo})$ \\
\hline Betula nana & $3 \pm 1 \mathrm{a}^{1}$ & $3 \pm 1 \mathrm{a}$ & $5 \pm 1 \mathrm{a}$ & $4 \pm 1 \mathrm{a}$ \\
Total lichen & $7 \pm 1 \mathrm{a}$ & $9 \pm 2 \mathrm{a}$ & $20 \pm 2 \mathrm{~b}$ & $86 \pm 2 \mathrm{c}$ \\
Cetraria nivalis & $5 \pm 2 \mathrm{a}$ & $7 \pm 2 \mathrm{a}$ & $17 \pm 2 \mathrm{~b}$ & $21 \pm 2 \mathrm{~b}$ \\
C. delisei & $0 \pm 0 \mathrm{a}$ & $0 \pm 0 \mathrm{a}$ & $5 \pm 2 \mathrm{~b}$ & $12 \pm 6 \mathrm{~b}$ \\
Cladina rangiferina & $0 \pm 0 \mathrm{a}$ & $0 \pm 0 \mathrm{a}$ & $0 \pm 0 \mathrm{a}$ & $1 \pm 0 \mathrm{a}$ \\
C. mitis & $0 \pm 0 \mathrm{a}$ & $0 \pm 0 \mathrm{a}$ & $0 \pm 0 \mathrm{a}$ & $41 \pm 8 \mathrm{~b}$ \\
C. alpestris & $0 \pm 0 \mathrm{a}$ & $0 \pm 0 \mathrm{a}$ & $0 \pm 0 \mathrm{a}$ & $33 \pm 8 \mathrm{~b}$ \\
Alectoria spp. & $1 \pm 0 \mathrm{a}$ & $0 \pm 0 \mathrm{a}$ & $2 \pm 1 \mathrm{a}$ & $1 \pm 1 \mathrm{a}$ \\
Stereocaulon paschale & $0 \pm 0 \mathrm{a}$ & $0 \pm 0 \mathrm{a}$ & $0 \pm 0 \mathrm{a}$ & $4 \pm 2 \mathrm{a}$ \\
\hline
\end{tabular}

${ }^{1}$ Different letters indicate significant difference $(p<0.05)$ using Kruskal-Wallis ANOVA with Dunn's test.

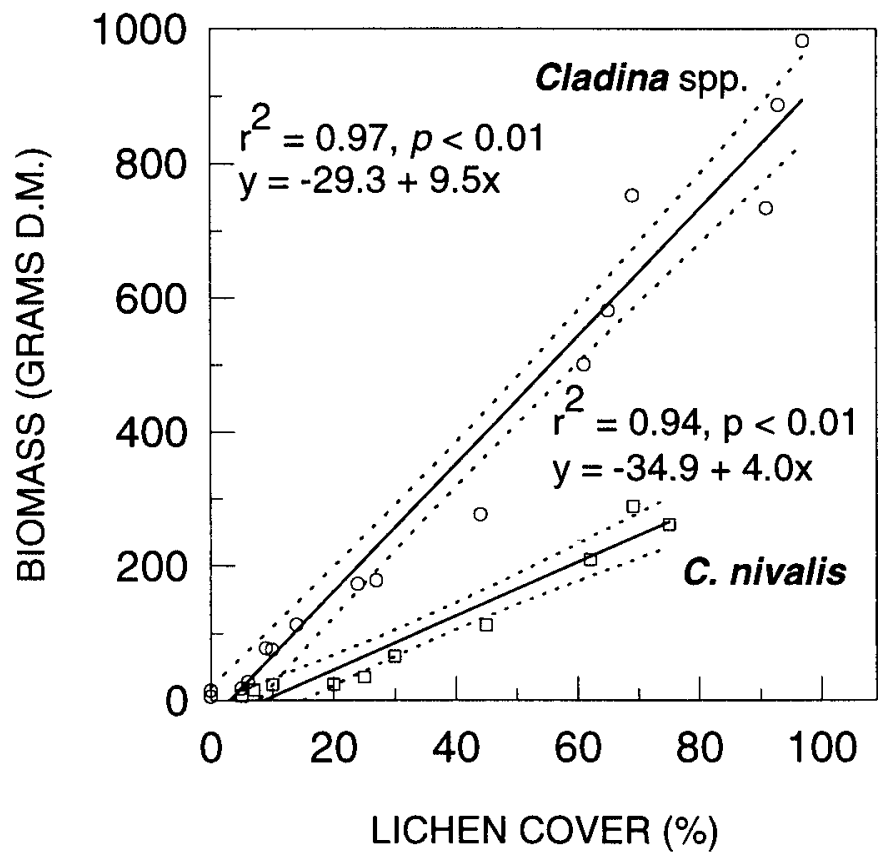

FIG. 5. Relationship between biomass (grams d.m.) and cover of lichens. Field sampling done in Dovre Mountains, Norway in 1993.

microcharacteristics. Many small rocks and microtopographic diversity create small snow traps, thus protecting lichen cover from frost and wind, and favouring its growth (Benedict, 1991; Sonesson et al., 1994). In addition, shallow snow on narrow ridges reduces energy expenditures associated with cratering and locomotion (Thing, 1977; Telfer and Kelsall, 1979; Fancy and White, 1985, 1987). Avoidance of ridges with a high density of larger boulders is not clearly understood, although these ridges also had relatively low lichen biomass. Avoidance could represent predator avoidance (Helle et al., 1990), since such ridges provide little overview, but the study did not adequately address this issue. 
The low biomass on narrow ridges relative to large alpine communities has implications regarding remote sensing of reindeer winter habitats. Ridges that are only $15-25 \mathrm{~m}$ wide seldom show on satellite imagery, e.g. LANDSAT TM5 $(30 \times 30 \mathrm{~m}$ pixels $)$ or on SPOT $(20 \times 20 \mathrm{~m}$ pixels $)$, unless ridges are very long (Richards, 1993). However, when measured at a mesoscale, narrow ridges are usually represented, making it possible to map distribution of lichen heaths relative to terrain ruggedness and, hence, predict late winter forage availability.

Forage estimates based solely on remotely sensed distribution of alpine communities may thus seriously overestimate carrying capacity in late winter, when forage availability is most limited. Such mapping should therefore be used primarily for estimating forage availability in fall and early winter, when even those types of lichen communities on large ridges are generally available. During early winter, forage estimates based on vegetation distribution may also be improved if integrated with remotely sensed information regarding coarse level terrain features, such as may be identified using special techniques for interpretation of satellite imagery (Albregtsen and Gulbrandsen, 1990). Integration of remotely sensed vegetation distribution with terrain ruggedness indices may enable a more accurate assessment of late winter reindeer carrying capacities by defining that proportion of lichen heath that is actually available in rugged terrain. The carrying capacity must further be evaluated in relation to body condition of reindeer and availability of spring and summer forage (Reimers, 1972, 1977; Reimers et al., 1983; Nellemann and Thomsen, 1994), although good access to forage during late winter likely is a prerequisite for successful replenishing of body resources during summer (Helle and Kojola, 1994).

The often scattered distribution of preferred patches of rugged terrain emphasizes the importance of reindeer having unrestricted travel across the landscape, and stresses the need for undisturbed access to forage for the reindeer (Reimers, 1980, 1983b; Helle and Särkelä, 1993). Strong preference by reindeer for an apparently small percentage of available habitat with a scattered distribution within their winter grounds, suggests that reindeer may be particularly vulnerable to fragmentation and disturbance in their habitats by tourism, roads, powerlines, and pipelines (Helle and Särkelä, 1993; Nellemann and Cameron, 1996).

\section{ACKNOWLEDGEMENTS}

I would like to thank JonOve Scheie and Erik Ellingsberg for assistance in the field, and Olav Hjeljord and Martin Smith for helpful comments on the manuscript. I am also grateful to Bjørn and Mari at Kongsvoll for their hospitality during fieldwork. We miss Bjørn dearly. The project was funded by the Reindeer Administration in Norway.

\section{REFERENCES}

AAGNES, T.H., and MATHIESEN, S.D. 1994. Food and snow intake, body mass and rumen function in reindeer fed lichen and subsequently starved for 4 days. Rangifer 14:33-37.

ADAMCZEWSKI, J.Z., BATES, C.C., SOUTAR, B.M., and HUDSON, R.J. 1988. Limiting effects of snow on seasonal habitat use and diets of caribou (Rangifer tarandus groenlandicus) on Coats Island, Northwest Territories, Canada. Canadian Journal of Zoology 66:1986-1996.

ALBREGTSEN, F., and GULBRANDSEN, L. 1990. Scale-space detection of exposed ridges as available reindeer winter grazing areas in Svalbard. In: Johnson, H., ed. Proceedings from the National Conference on Image Processing and Remote Sensing, 28-29 May 1990, Troms $\varnothing$, Norway. 71-75.

BASKIN, L.M. 1990. Population dynamics of reindeer. Rangifer Special Issue 3:151-156.

BENEDICT, J.B. 1991. Experiments on lichen growth II. Effects of a seasonal snow cover. Arctic and Alpine Research 23: $189-199$.

BERGERUD, A.T. 1974. Relative abundance of food in winter for Newfoundland caribou. Oikos 25:379-387.

BROOKS, J., III, and COLLINS, W.B. 1984. Snow cover and interpretation of vegetation/habitat inventories. In: Inventorying forest and other vegetation of the high latitude and high altitude regions. Proceedings of an International Symposium Society of American Foresters Regional Technical Conference, 23-26 July, 1984, Fairbanks, Alaska. 203-210.

COLLINS, W.B., and SMITH, T.S. 1991. Effects of wind-hardened snow on foraging by reindeer (Rangifer tarandus). Arctic 44: $217-222$.

DAHL, E. 1956. Mountain vegetation in South Norway and its relation to the environment. Ph.D. dissertation, University of Oslo, Norway. Skrifter Norsk Vitenskaps Akademi 3:1-174.

DUQUETTE, L.S. 1988. Snow characteristics along caribou trails and within feeding areas during spring migration. Arctic 31: $143-144$.

FANCY, S.G., and WHITE, R.G. 1985. Energy expenditures by caribou while cratering in snow. Journal of Wildlife Management 49:987-993.

FANCY, S.G., and WHITE, R.G. 1987. Energy expenditures for locomotion by barren-ground caribou. Canadian Journal of Zoology 65:122-128.

GAARE, R., and SKOGLAND, T. 1975. Wild reindeer food habits and range use at Hardangervidda. In: Wielgolaski, F.E., ed. Ecological studies. Vol. 17: Analysis and synthesis. Fennoscandian Tundra Ecosystems, Part 2. Berlin: SpringerVerlag. 195-205.

GATES, C.C., ADAMCZEWSKI, J., and MULDERS, R. 1986. Population dynamics, winter ecology and social organization of Coats Island caribou. Arctic 39:216-222.

HALL, D.K., STURM, M., BENSON, C.S., CHANG, A.T.C., FOSTER, J.L., GARBEIL, H., and CHACHO, E. 1991. Passive microwave remote and in situ measurements of arctic and subarctic snow covers in Alaska. Remote Sensing of the Environment 38:161-172. 
HELLE, T. 1984. Foraging behavior of the semidomestic reindeer (Rangifer tarandus L.) in relation to snow in Finnish Lapland. Report from the Kevo Subarctic Research Station 19:35-47.

HELLE, T., and KOJOLA, I. 1994. Body mass variation in semidomesticated reindeer. Canadian Journal of Zoology 72: 681-688.

HELLE, T., and SÄNTTI, V. 1982. Winter catastrophes in the reindeer husbandry of Finland: Losses and their prevention. Rangifer 2:2-8.

HELLE, T., and SÄRKELÄ, M. 1993. The effects of outdoor recreation on range use by semi-domesticated reindeer. Scandinavian Journal of Forest Research 8:123-133.

HELLE, T., ASPI, J., and KILPELÄ, S.S. 1990. The effects of stand characteristics on reindeer lichens and range use by semidomesticated reindeer. Rangifer, Special Issue 3:107-114.

HENSHAW, J. 1968. The activities of wintering caribou in northwestern Alaska in relation to weather and snow conditions. International Journal of Biometeorology 12:21-27.

HYVÄRINEN, H., HELLE, T., NIEMINEN, M., VÄYRYNEN, P., and VÄYRYNEN, R. 1977. The influence of nutrition and seasonal conditions on mineral status in the reindeer. Canadian Journal of Zoology 55:648-655.

JANDEL. 1992. SIGMASTAT Statistical Software, User's manual. Erkrath: Jandel Scientific GmbH. 698 p.

LAPERRIERE, A.J., and LENT, P.C. 1977. Caribou feeding sites in relation to snow characteristics in northeastern Alaska. Arctic 30:101-108.

LARSSON, J.Y., and REKDAL, Y. 1991. Veiledning i vegetasjonskartlegging (Vegetation mapping and classification). Report from the Norwegian Institute of Land Inventory. Ås, Norway. 93 p. (In Norwegian).

McEWAN, E.H., and WHITEHEAD, P.E. 1970. Seasonal changes in the energy and nitrogen intake in reindeer and caribou. Canadian Journal of Zoology 48:905-913.

MILLER, F.L., RUSSELL, R.H., and GUNN, A. 1975. The recent decline of Peary caribou on Western Queen Elizabeth Islands of Arctic Canada. Zeitschrift der Deutschen Gesellschaft für Polarforschung Münster 45:17-21.

NELLEMANN, C., and THOMSEN, M.G. 1994. Terrain ruggedness and caribou forage availability on the arctic coastal plain, Alaska. Arctic 47:361-367.

NELLEMANN, C., and FRY, G. 1995. Quantitative analysis of terrain ruggedness in reindeer winter grounds. Arctic 48:172176.

NELLEMANN, C., and CAMERON, R.D. 1996. Effects of petroleum development on terrain preferences of calving caribou. Arctic 49:23-28.

NEU, C.W., BYERS, C.R., and PEEK, J.M. 1974. A technique for analysis of utilization-availability data. Journal of Wildlife Management 38:541-545.

NIEMINEN, M., and HEISKARI, U. 1989. Diets of freely grazing and captive reindeer during summer and winter. Rangifer 9:1734.

PEARCE, C.M. 1991. Mapping muskox habitat in the Canadian High Arctic with SPOT satellite data. Arctic 44 (Suppl. 1):49-57.

PRUITT, W.O. 1966. Animals in the snow. Scientific American 202:60-68.
1979. A numerical snow index for reindeer (Rangifer tarandus) winter ecology (Mammalia, Cervidae). Annales Zoologici Fennici 16:271-280.

. 1981. Application of the Värriö snow index to overwintering North American barren-ground caribou (Rangifer tarandus arcticus). Canadian Field-Naturalist 95:363-365.

REIMERS, E. 1972. Growth in domestic and wild reindeer in Norway. Journal of Wildlife Management 36:612-619.

- 1977. Population dynamics in two subpopulations of reindeer in Svalbard. Arctic and Alpine Research 9:369-381.

- 1980. Activity pattern: The major determinant for growth and fattening in Rangifer? In: Reimers, E., Gaare, E., and Skjenneberg, S., eds. Proceedings of the 2nd International Reindeer/Caribou Symposium, Røros, Norway. Trondheim: Direktoratet for Vilt og ferskvannsfisk. 466-474.

1982. Winter mortality and population trends of reindeer on Svalbard, Norway. Arctic and Alpine Research 14:295-300.

1983a. Mortality in Svalbard reindeer. Holarctic Ecology 6:141-149.

- 1983b. Growth rate and body size differences in Rangifer: A study of causes and effects. Rangifer 3:3-15.

REIMERS, E., KLEIN, D.R., and SØRUMGÅRD, R. 1983. Calving time, growth rate and body size of Norwegian reindeer on different ranges. Arctic and Alpine Research 15:107-118.

RICHARDS, J.A. 1993. Remote sensing digital image analysis. Berlin Heidelberg, New York: Springer-Verlag. 333 p.

ROBY, D.D., and THING, H. 1985. Behaviour of West Greenland caribou during a population decline. Holarctic Ecology 8: $77-87$.

SCOTTER, G.W. 1966. The winter diet of barren-ground caribou in northern Canada. Canadian Field-Naturalist 81:33-39.

SKOGLAND, T. 1978. Characteristics of the snow cover and its relationship to wild mountain reindeer (Rangifer tarandus tarandus L.) feeding strategies. Arctic and Alpine Research 10:569-580.

1983. The effects of density dependent resource limitation on size of wild reindeer. Oecologia 60:156-168.

- 1984. Wild reindeer foraging-niche organization. Holarctic Ecology 7:345-379.

- 1985. The effects of density-dependent resource limitations on the demography of wild reindeer. Journal of Animal Ecology 54:359-374.

1986. Density-dependent food limitation and maximal production in wild reindeer herds. Journal of Wildlife Management 50:314-319.

SONESSON, M., OSBORNE, C., and SANDBERG, G. 1994. Epiphytic lichens as indicators of snow depth. Arctic and Alpine Research 26:159-165.

STAALAND, H., BRATTBAKK, I., EKERN, K, and KILDEMO, K. 1983. Chemical composition of reindeer forage plants in Svalbard and Norway. Holarctic Ecology 6:109-122.

STAALAND, H., HOVE, K., and WHITE, R.G. 1986. Mineral absorption in relation to nutritional ecology of reindeer. Rangifer Special Issue 1:279-287.

TELFER, E.S., and KELSALL, J.P. 1979. Studies of morphological parameters affecting ungulate locomotion in snow. Canadian Journal of Zoology 57:2153-2159. 
THING, H. 1977. Behaviour, mechanics and energetics associated with winter cratering by caribou in northwestern Alaska. Biological Papers of University of Alaska 18:1-41. . 1984. Feeding ecology of the West Greenland caribou (Rangifertarandus groenlandicus) in the Sisimiut-Kangerlussuaq region. Danish Review of Game Biology 12:1-55.

THOMAS, D.C., and HERVIUX, D.P. 1986. The late winter diets of barren-ground caribou in north-central Canada. Rangifer Special Issue 1:305-310.

THOMAS, D.L., and TAYLOR, E.J. 1990. Study designs and tests for comparing resource use and availability. Journal of Wildlife Management 54:322-330.

THOMPSON, D.C., and McCOURT, K.H. 1980. Seasonal diets of the Porcupine Herd. The American Midland Naturalist 105: $70-76$.
TØMMERVIK, H., JOHANSEN, B.E., and EIRA, A.N. 1990. Mapping air pollution impact to reindeer range areas in Pasvik, northern Norway using satellite imageries. Rangifer Special Issue 4:19-20.

TUCKER, B., MAHONEY, S., GREENE, B., MENCHENTON, E., and RUSSELL, L. 1991. The influence of snow depth and hardness on winter habitat selection by caribou on the southwest coast of Newfoundland. Rangifer Special Issue 7:160-163.

TYLER, N.J.C., and BLIX, A.S. 1990. Survival strategies in arctic ungulates. Rangifer Special Issue 3:211-230.

WRATTEN, S.D., and FRY, G. 1980. Field and laboratory exercises in field ecology. London: Edward Arnold Publishers. 227 p. 